$\begin{array}{ll} & \text { Etnográfica } \\ \text { etnográfica } & \text { Revista do Centro em Rede de Investigação em }\end{array}$

Antropologia

vol. 22 (1) | 2018

Vol. 22 (1)

\title{
When borders transnationalize people: reframing the migrant transnationalism in the Andean tri- border area
}

Quando as fronteiras transnacionalizam as pessoas: repensar o

transnacionalismo migrante na tríplice fronteira andina

\section{Menara Guizardi}

\section{(2) OpenEdition}

\section{Journals}

Electronic version

URL: https://journals.openedition.org/etnografica/5197

DOI: 10.4000/etnografica.5197

ISSN: 2182-2891

\section{Publisher}

Centro em Rede de Investigação em Antropologia

Printed version

Date of publication: 1 February 2018

Number of pages: 169-194

ISSN: 0873-6561

\section{Electronic reference}

Menara Guizardi, "When borders transnationalize people: reframing the migrant transnationalism in the Andean tri-border area", Etnográfica [Online], vol. 22 (1) | 2018, Online since 17 May 2018,

connection on 20 January 2022. URL: http://journals.openedition.org/etnografica/5197 ; DOI: https:// doi.org/10.4000/etnografica.5197

\section{(c) (†) \&}

Etnográfica is licensed under a Creative Commons Attribution-NonCommercial 4.0 International License. 


\section{When borders transnationalize people: reframing the migrant transnationalism in the Andean tri-border area}

\section{Menara Guizardi}

This article derives from ethnographic studies developed in the Northern Chilean territories that lie adjacent to Peru and Bolivia. The research results suggest that the daily activities of transborder inhabitants generate frictions between the local inscription of social practices, and the transnationalization of communitarian knowledge, economies and memories. These frictions situationally update the national identities in these areas. Over the last two decades, an idea has prevailed in migratory studies that the migrant's border crossings articulate transnational social fields between origin and host societies, leading to a globalization "from below." Ethnographic findings defy this conception, since the social networks and practices that interconnect these borderlands predate the establishment of the national frontiers. It was not the communities who transnationalized the territories: the borders transnationalized them. I will illustrate this assertion by ethnographically following Joanna, an Aymaran shepherdess that found a transnational solution to the lack of successors to her shepherding activities.

KEYWORDS: borders, transnationalism, migration, Andean tri-border area, shepherding.

Quando as fronteiras transnacionalizam as pessoas: repensar o transnacionalismo migrante na tríplice fronteira andina - O artigo resulta de estudos etnográficos realizados em territórios do Norte chileno adjacentes ao Peru e à Bolívia. Os resultados da pesquisa sugerem que as atividades dos habitantes transfronteiriços geram fricções entre a inscrição local das práticas sociais e a transnacionalização de conhecimentos, economias e memórias. Estas fricções atualizam situacionalmente as identidades nacionais nestes espaços. Nas últimas duas décadas, predominou nos estudos migratórios a conceção de que os cruzamentos de fronteira pelos migrantes articulam campos sociais transnacionais entre origem e destino, conduzindo a uma "globalização por baixo". Os achados etnográficos desafiam esta conceção, pois as redes sociais e práticas que interconectam as áreas estudadas antecedem o estabelecimento das fronteiras nacionais. Não foram as comunidades que transnacionalizaram os territórios, foram as fronteiras. Ilustrarei esta afirmação seguindo etnograficamente a Joana, pastora aimará que encontrou uma solução transnacional para a falta de sucessores nas suas atividades de pastoreio.

PALAVRAS-CHAVE: fronteiras, transnacionalismo, migração, tríplice fronteira andina, pastoreio.

GUIZARDI, Menara (menaraguizardi@yahoo.com.br) - National Council of Scientific and Technological Research of Argentina (Conicet), Institute for Advanced Studies in Social Sciences, National University of San Martín (IDAES-UNSAM), Argentina; University of Tarapacá (UTA), Chile. 


\section{INTRODUCTION}

The present article seeks to contribute to the reframing of the transnational perspective of migration, through an anthropological approach. Such an objective leads to two central epistemological questions that I assumed as the starting point of my reflections on the topic. Firstly, there is the necessity to situate what I understand as the contemporary "anthropological approaches," defining them as constituted by diverse theoretical perspectives (Clifford 1997: 192), articulated by the ethnographical fieldwork (Des Chene 1997: 69-70), and oriented to solve (even if temporally) the "methodological anxieties" that have been stunning the anthropologists since the end of the last century (Marcus 1995: 99). These anxieties foster the critical recognition of the limitations of classical ethnographical approaches, whenever they are applied to social spaces reshaped by the dialectic of junctions and disjunctions triggered by globalization (Gupta and Ferguson 1997). The expiration of anthropology's "traditional" methodological tools is particularly noticed in border territories (Kearney 1991: 52), such as the villages addressed in this text.

Secondly, we need to resize some categories of transnationalism that are inadequate when explaining mobility in border areas where migrant experiences usually differ from the practices most frequently described in transnational studies. The social networks and the cultural capital that interconnect national borderlands often rely on constitutive experiences of space that precede the definition of national frontiers. In cross-border areas, transnationalism is more than an overlap of "new and changing practices" developed by people as a result of recent access to advanced technologies in transportation and communication. For anthropologists working in border areas, the questioning regarding the theoretical adequacy of transnationalism has an epistemological dimension closely connected with the discipline's foundational problems: we face the difficulty of historicizing the ethnographical understanding of social spaces.

Both reflections were particularly inspired by the ethnographic experiences I lived between 2011 and 2015, in the framework of two research projects that investigated human mobility in the Great North (Norte Grande) of Chile. ${ }^{1}$ Situated in the Atacama Desert, the Great North is composed of three regions from the current political-administrative division of the country: Arica and Parinacota (with its capital in Arica), Tarapacá (with its capital in Iquique), and Antofagasta (with its capital in the homonymous city). ${ }^{2}$ There are many kilometers of international border zones in these territories, which include

1 These projects are Fondecyt 11121177 , that I directed between 2012 and 2015, and Fondecyt 111 10246, directed by Alejandro Garcés (2011-2014). I would like to thank the Chilean National Commission of Scientific and Technological Research which funded both projects, and to Christine Ann Hills, for the careful and invaluable language review.

2 The capitals are located at the Pacific's coast, and are important port cities since colonial times. 
eight legal (and uncountable illegal) border-crossing points, and two international tri-border areas (TBAs). One of them is the Andean TBA, formed by the meeting of Chilean, Peruvian and Bolivian territories. This TBA is located on the Andean Plateau of the region of Arica and Parinacota, on the Chilean side.

The lives of the Atacama social groups carry a historically intense commercial and human mobility (Amilhat 2007) across the four orographic platforms that make up the territory from the Pacific coast to the Andean peaks (Dillehay and Núñez 1988), and in turn from them to the Andean region of Bolivia (where the cities of El Alto, La Paz, Oruro and Potosí are situated). ${ }^{3}$ Nevertheless, Atacama's commercial interconnection was violently reshaped by the conformation of national borders in the $19^{\text {th }}$ century, after the War of the Pacific (1879-1883). In the conflict, Chile confronted Peru and Bolivia, fighting for mining territories of the Great North (Vitale 2011: 387), which were occupied by the Chilean army. The Chilean victory founded the ideology of a supposed racial difference between Chileans, on the one hand, and Peruvians and Bolivians on the other (Beckman 2009), linking the latter with an indigenous identity associated with barbarism and a lack of civilization (McEvoy 2011: 15). These race-identity ideologies were crossed with the militarization of the Andean TBA and gender patterns: Peruvian and Bolivian women, especially the indigenous, were systematically raped by Chilean military during and after the conflict (Sater 2007: 92). ${ }^{4}$ The war also caused a violent disruption of family ties and communitarian practices of the Atacama indigenous groups (Díaz 2006).

In Chile, since the 90s, the national imaginaries about the supposed indigenous condition of its neighboring countries are being re-activated due to the

3 Since the $16^{\text {th }}$ century there are intense commercial routes between Potosí, the cities of the Pacific's coast (such as Arica and Ilo), and localities of the Peruvian highlands (such as Arequipa and Cuzco) (Sempat 1995: 110). Through these routes, silver and other precious metals were transported from Potosí to the ports, while food and supplies were taken back to the mining regions (Larson 1995: 26; Stern 1995: 77). Women from Potosí and from the Andean Plateau were protagonists of both the transportation and urban sale of these supplies (Mangan 2005: 134-160).

4 The borders with Bolivia were established in 1904, through the "Treaty of Peace and Friendship" (González 2011). The agreement formalized the transfer of the Antofagasta region to Chile, establishing that Bolivia would have the right to use the port of Arica without taxation (since the country lost its coastal territories), and that Chile would finance the construction of a railway connecting Arica to the Bolivian capital (La Paz). On the other hand, Chile and Peru agreed the end of conflict in 1883, through the "Treaty of Ancón." The latter formalized the transfer of Tarapacás territory to Chile and established that the provinces of Arica and Tacna, to that date Peruvian (and the northernmost area invaded by Chile) would be controlled by Chilean authorities and laws for 10 years. After this period, a plebiscite would be held to foster a people's decision about the sovereignty of both provinces (Tapia 2012: 181). The referendum never took place, and the provinces remained occupied by the Chilean army for 46 years. The quest was formally solved, avoiding the people's participation, with the signature of the "Treaty of Lima" (1929), which defined Tacna as Peruvian, and Arica as Chilean (González 2006). It also delimited the national borders in the Andean Plateau, creating the Andean TBA milestone. 
intensification of Peruvian and Bolivian migration, enhanced by Chile's economic growth, and by the end of its dictatorial period (Tapia 2012). ${ }^{5}$ The Great North concentrates higher proportions of migrants of both nationalities that declare themselves indigenous (Guizardi and Garcés 2012), but their migration is conditioned by the communitarian, family and commercial networks they have with the Chilean indigenous (Rojas and Bueno 2014). It is also triggered by these family network strategies: including mining activities, self-managed business ventures (hostels, restaurants, travel tickets or food stores), domestic and care work, agricultural labor, construction activities, smuggling, commerce and transportation.

My interest in understanding the role of women in the border movements of these territories was deepened due to the ethnographic project I directed between 2012 and 2015 (see footnote 1), which compared the migrant experience of Peruvian women in two cities of the North (Arica and Iquique) and the two cities of the center (Valparaíso and Santiago) of Chile. The study was developed by a team of researchers through a mixed qualitative and quantitative methodological approach, articulated through the conjunction of the extended case method (ECM) and multi-sited ethnography (ME). ${ }^{6}$ Between 2012 and 2013, we carried out ethnography on various spaces through which migrant women used to circulate in those cities: residences, hostels, shantytowns, Catholic church welfare facilities, work and leisure environments, state offices, public health posts, and public schools. ${ }^{7}$ Between 2013 and 2014, we conducted a survey on 400 Peruvian female migrants (100 in each city). ${ }^{8}$

5 In the North of Chile, this intensification of migrations responds to other macrosocial aspects, such as the increase of global circuits of international capitals in this area. It is connected to the dynamization of the activities between the tax-free zones placed in Iquique (ZOFRI, Chile), and in Tacna (ZOFRA, Peru), which constitute enclaves of the Chinese commercial expansion in Latin America. It is also articulated to the massive expansion of Chilean mining industry fostered by the entry of international capitals in the sector (Tapia 2012).

6 Multi-sited ethnography employs strategies of fieldwork mobility allowing researchers to subvert the categorical isomorphism between space and culture that cements the praxis of classical Malinowski ethnographic techniques (Marcus 1995). The extended case method, which will be explained below, advocates historicizing and extrapolating ethnography to macro-social dimensions through the emphasis on disruptive interactions (the "social situations") and the use of quantitative data (Gluckman 2006). Of Marxist inspiration, the extended case method understands ethnography as praxis.

7 In Arica and Parinacota, we conducted 87 in-depth interviews. Among them, 32 are life-story interviews carried out with migrant women. The other 55 are semi-structured interviews developed with: male Peruvian migrants (10); female Bolivian who lived in shantytown neighborhoods with Peruvian woman (6); community leaders of the migrant shantytown neighborhoods (3); NGO staff and officials from public health and educational centers (21); Peruvian women imprisoned at Arica's Acha Prison (15). We also recorded about 250 ethnographic photographs and developed a systematic ethnographical diary for the whole period of team fieldwork.

8 The survey complemented the qualitative results from the first year. It contained 106 questions divided into twelve areas of inquiry: (1) socio-demographic information; (2) migratory displacement and itineraries; (3) access to formal education; (4) labor occupation; (5) civil status; [continues] 
Between 2014 and 2015, we digitized and systematized the survey data using geographic information software (GIS). Finally, we contrasted and analyzed all the data.

Nevertheless, since the first year of the study, I decided to expand our areas of action towards the highland villages of the Atacama Desert, seeking to identify if the migratory experiences of the Peruvian women were also connected with these inner localities. The present article derives, precisely, of one of these experiences. When I first started field-working in these territories, my ethnography of the migrants' social experiences was oriented to the transnational practices they built over the national spaces along their displacement routes and itineraries. Incurring a sort of "methodological transnationalism," I assumed that this "new" transborder migration would become the main impulse of the transnationalization of Northern Chilean communities. Ethnography allowed me to understand the naivety of such initial assumptions, forcing me to confront the complex diachronic dimension of the transnationalization of these territories.

Redoubling my attention on the subjects who were not international migrants, I observed how the new transnational practices always emerged in these spaces with a (metaphorical, metonymical or allegorical) connection to translocal activities that precede the establishment of national states' frontiers. The latter does not imply the inexistence of new ways of transnationalism associated to the intensification of international migration in the Great North. These "new ways" are actually framed by historical and contextual social references, and thus, they owe part of their existence to the memory of translocal patterns of displacement across territories that are now separated by national borders.

Following these findings, the present article states that migratory transnationalism in the Great North is strongly tied to ancient translocal practices that were intercepted (or interrupted) by the establishment of national borders. Due to the vicissitudes of the current economic, social and political contexts, transborder inhabitants are operating a creative transnationalization of these translocal practices. The "Chilean locals" acquire great importance in this process, articulating the ancient pre-border practices to new patterns of spatial interconnection. Therefore, the transnational subjects of these border territories are not exclusively international migrants.

With these ideas in mind, I will recover ethnographic examples that tension two key arguments of the transnational perspective of migrations: (1) the assumption that the migrant agency is a central impulse for transnationalism "from below" (Portes 2003); (2) and the supposition that globalization implies a substantive change in the contents of transnational relations. My criticisms

(6) residential situation; (7) documental paperwork situation; (8) maternity, children and family;

(9) remittances; (10) gender relations; (11) experiences of violence and (12) reasons to migrate. 
will be exemplified through the story of Joanna, an Aymaran shepherdess from Visviri (a village on the Chilean side of the Andean TBA) who has had to find a transnational solution to the lack of successors to her activities. Although far from being the "classic" transnational migrant subject, Joanna leads transnational relations that foster transborder mobility and migrations.

Nonetheless, my description of Joanna's story entails a critical strategy regarding the epistemological relation between the classic ethnographic narrative and anthropologists' synchronic interpretation of social life. Following extended case method (EMC) proposals, I will articulate Joanna's story through a specific "social situation": accompanying her on a daily experience and emphasizing the procedural rhythm of the scenes, dialogues and misunderstandings lived on this day. ${ }^{9}$ The challenge proposed here is to situate the narrative of this social situation, of these "stories" of people, "in wider worlds of power and meaning that gave them life" (Comaroff and Comaroff 1992: 17), in which the historical dimensions of the phenomena can constitute (dialectically) the experiences I am narrating, and the theoretical criticism that I wish to bring to light.

\section{ETHNOGRAPHY, NATIONAL BORDERS AND MIGRANT}

\section{TRANSNATIONALISM}

Classical social anthropology hegemonized the understanding of the interrelation between the notions of space, community and culture as isomorphic (Gupta and Ferguson 1997), naturalizing the existence of borders that would allegedly frame each social group in a specific "cultural area" (Hannerz 1986). This conceptualization overflowed from the national borders' political categories into the anthropological theorization of culture (Gupta and Ferguson 1997), and became hegemonic from the end of the $19^{\text {th }}$ century (Clifford

9 ECM implies four aspects that differentiate it from classical anthropological approaches. (1) It implies an alternative way of treating empirical material derived from fieldwork. Instead of quoting "examples from ethnography in apt illustration of general ethnographical and analytical statements" (Evens and Handelman 2006: 5), it proposes "to turn this relationship between case and statement on its head: the idea is to arrive at the general through the dynamic particularity of the case" (Burawoy 1998: 5). (2) It focuses on the study of social situations, understood as "a series of specific incidents affecting the same persons or groups, through a long period, and showing how these incidents, these cases, are related to the development and change of social relations among these persons or groups" (Gluckman 2006: 17). In the social situations, the ethnographer observes how the connection between social coercion and individual action obliges subjects to "place themselves," to restrict their action to a specific interpretation of values (Evens 2006: 53). (3) It implies diachronically understanding the daily social situations observed, establishing interdisciplinarity with historic studies (Gluckman 2006). (4) The analytical process should aim towards the interpretative extension of the particularities of the social situations, contrasting the empirical data with the reconstruction of the macroeconomic, social and political context (Mitchell 2006: 37). 
1997). Anthropologists worldwide projected their objects of study as "the others," defining this category as a social group different from that of the ethnographer: due both to an alleged radically different cultural background, and to their location in someplace else, far from the anthropologists' own societies. This political (and ethnocentric) bias turned anthropology into a science obsessed in finding the most "other among others," and to narrate this other's social life in a style in which "small is beautiful" (Hannerz 1986: 364).

Theoretically, this assertion was provided by the excessive focus on the social cohesion and structure (understood as an ordered system) and on the synchronicity of the "other's" social life (Fabian 2002: 25). The naturalization of that belief in synchrony establishes a dichotomist appreciation of the relation between persons and social groups (between agency and structure) (Comaroff 2013). It promotes an anthropologically selective blindness, discouraging ethnographers from dealing with the conflictive relation between social customs and hierarchies, and the person's situational strategies to both reproduce and break this state of affairs (Evens 2006). The synchronic perspective also prevents ethnographers from properly relativizing the hegemonic ways through which the local and national societies build the differentiation between "we" and "the others." So, defining how these two categories ("we" and "the others") are produced in a certain historical context, in a particular locality, should be the starting point of a critical anthropological perspective, attentive to avoid reproducing the nation-state mythologies regarding the supposed homogeneity of the imagined national community (Fabian 2002: xx).

These reflections enable me to add two other elements to those I discussed in the introduction as constitutive of my methodological anxieties and, thus, of my anthropological perspective: the necessity to historicize ethnography, and to redouble attention to the ways of developing ethnographic accounts. From my point of view, the diachronic perspective in anthropology must be connected to the effort to create narrative practices that allow the expression of the contradictions between local spaces and global dynamics. It must also avoid discursive usages that frame the relation between agency and structure (among others) as a dichotomy.

This critical approach in anthropology can only be understood as part of a context: it has caused and has been caused by the social and political changes in the experience of border crossings over the past three decades. Since the end of the $80 \mathrm{~s}$, globalization has increased the compression of the time-space relationship, challenging the Euclidian space perspectives that modern geography juxtaposed onto the border concept. The notion of a border as a dividing line that separates peoples, processes and things no longer served to describe movements between nation-states. Cross-border regions situated on the confluence of two or more national spaces emerged as the central axis for the research (Perkmann and Sum 2002), as areas that condense multi-scale phenomena 
(Sum 2003) that defy two founding ideologies of the nation-state: firstly, the (ethnic, phenotypic and cultural) separation of those who belong to the country from "the others"; and secondly, the idea of the existence of a demarcated spatial limit circumscribing the social processes that would presumably belong to the nation (Kearney 1991).

In the 90s, Anglo-Saxon anthropology began to theorize about border spaces from the tension between subject, history and culture (Grimson 2003: 15). Kearney (2004), for example, argued that border regions are crossed by three political aspects constituent of their spatiality: literal borders, in the form of political-territorial demarcations, identities crossed by ethnic, class and nationality variables, and political systems (official and nonofficial organizations responsible for charting and enforcing political-identity limits). Then, these would be plural spaces where nation-states act structurally, while subjects act re-interpreting and negotiating the classificatory hierarchy of the state (Brenna 2011: 12).

Anthropologists of South American border regions have followed these reflections, arguing that the porosity of borders "does not necessarily imply a modification of identity classifications and national auto-affiliations. Rather the presence of the border allows the organization of a social system of exchanges between groups that consider themselves different" (Grimson 2000: 28). The fact that people cross borders does not mean that said borders disappear. The judicial, political, economic and identity asymmetries between neighboring countries promote the emergence of social practices that seek to benefit from these differences, from the liminality between legal and illegal, and between belonging and being uprooted (Grimson 2005). From a critical approach, I consider that the border condition alters the way in which the acts of people or social groups and the macro-structural characteristics of the context breed the construction of "the local," implying, simultaneously, mutual conformation processes with "global" phenomena (Kearney 1995; Perkmann and Sum 2002). ${ }^{10}$ This double relationship is inherently dialectic (Kearney 1991, 1995) and problematic (Agnew 2008), articulating some changes in the borders in temporal horizons (such as compressed-time and memory-time of nations) and in spatial scales (such as global, regional, national and local

10 Ethnography in border territories requires an analytical sensitivity towards the nuances of the relationship between agency and structure. It demands adopting perspectives more attentive to those daily actions of the people that, unexpectedly, can give rise to major structural transformations. The critical perspective that I adhere to in this study refers, precisely, to the proposal of Jean Comaroff (2013), for whom this sensitivity is articulated through a "dialectical ethnographic approach." The latter is characterized by the effort to capture the reciprocal interaction of human practice, social structure and symbolic mediation (Comaroff 2013). It is also articulated with the ethnographic methodology used, the extended case method. For a detailed discussion on this critical perspective and its methodological implications, see Guizardi (2016). 
scales) (Sum 2003: 208). On the other hand, cross-border mobility summons us to deconstruct the patriarchal and masculine ideology and the invisibility of the importance of women in global movements (Freeman 2001).

These ideas regarding the junctions and disjunctions of transborder mobility raise some problems about the most hegemonic arguments of migration studies, which since the 90 s have been predominantly developed to explain the migration of global Southern populations moving to a metropolis of the global North (usually situated far from border areas). The border crossings are taken into consideration in these studies, but their analytical focus are the modes of interconnection that, due to globalization in communication and transport technologies, the migrants articulate between localities placed in different countries (separated by long distances one from another).

Since the end of $20^{\text {th }}$ century, the predominating idea in the social sciences is that the globalized condition of migrants materializes as transnational practices that consist of creating social fields that link the countries of origin and destination (Levitt and Jaworsky 2007). "Transmigrants" maintain family, economic, social, organizational, religious and political relationships across borders: they take decisions, show interest and negotiate identities with the social networks that connect them with at least two countries (Glick Schiller, Basch and Blanc-Szanton 1992). Therefore, transnational migration would lead to a globalization "from below" (Portes 2003) that tensions the states' limits. ${ }^{11}$

Various authors (Massey et al. 1993) understand this transnational social field as the link between migrant social and cultural capitals. Migrant social capital is defined as "the aggregate of the actual or potential resources which are linked to possession of a durable network of more or less institutionalized relationships of mutual acquaintance or recognition" (Bourdieu, in Portes 2000: 45). This durable network is not naturally given, but is weaved from strategies aimed at the institutionalization of group relations. Cultural capital would correspond to the knowledge incorporated by the migrants and spread through their networks. Consequently, the communities' axes would be their social networks and not their inscription upon a "cultural area." The transnational spatiality of the migrant communities relies on the frequency of practices that bring the communities together, and not on the literal spatial distance between the members of their networks (Besserer 2004: 8).

11 The experience of this sort of communitarian life produces a dialectic relation between "there" and "here" that is defined as an experience of social simultaneity (Levitt and Glick Schiller 2004). The spatiality that migrants create in the host society will be updated by practices, relations, identities, affections, desires and social hierarchies that come from other localities. This does not mean that the community becomes a-spatial, rather that its spatiality will demand an increased mobility from its subjects in spatial, symbolic and identity terms. So, the concept of simultaneity tensions the notion of spatial communitarian stability (the space-culture isomorphism) and identity stability (the community-identity isomorphism). 
The Andean TBA territories challenge part of these reflections because the social networks (and the cultural capital regarding migration) in these areas predate the establishment of the borders: mobility practices and human flows constitute experiences linked to even pre-colonial times. They are translocal practices that became cross-border with the establishment of the national borders: here it is not the subjects themselves who have transnationalized the territory "from below"; the border has transnationalized them. This inversion of logic supposes the need to measure the limits of the transnational perspective of migrations in explaining border movements. It implies extending the very concept of "migration" to include the processes of cross-border mobility and bi-residentiality that respond to the logic of circularity (Guizardi and Garcés 2013). It also implies reconsidering the definition of the transnational subject "par excellence" as an international migrant. The social situation I will narrate below will detail ethnographic evidence that can help to explain these affirmations.

\section{JOANNA AND THE (TRANSNATIONAL) STRATEGIES OF SUCCESSION IN THE ANDEAN TBA}

\section{Arriving at Visviri}

In December 2012, I visited for the first time the highlands of the Chilean region Arica and Parinacota to start my ethnography of the border experiences of those who live between the localities of Visviri (Chile), Ancomarca (Peru), and Charaña (Bolivia), where the Hito Tripartito (the Andean TBA's milestone) is placed. It was not exactly the best timing for such a trip: between December and March clouds originating in Bolivia gather strength to cross the mountains, and cause powerful rains and hailstorms on the Chilean side, often damaging the roads. ${ }^{12}$ This rainy season is known as the "Andean Plateau winter" (invierno altiplánico), but on the Chilean side, people refer to it as "the Bolivian winter."

Attributing a nationality to a climate phenomenon constitutes a noteworthy exercise in symbolism. It offers an excellent example of the production of meanings attributed to national boundaries and allegiances in these territories, being structured around a double semantic juxtaposition: the naturalization of the national, and the nationalization of ecology. Although outsiders find this a strange metonymy, this double juxtaposition goes unnoticed by Chilean state officials and non-indigenous people, who did not seem to understand why I was baffled by the attribution of Bolivian nationality to a climatic phenomenon that takes place in the North of Chile. Justifying the expression, some of those interviewed argued that the nationalization of the rains derives from an "incontestable fact": the clouds "really" did come from Bolivia. However, 

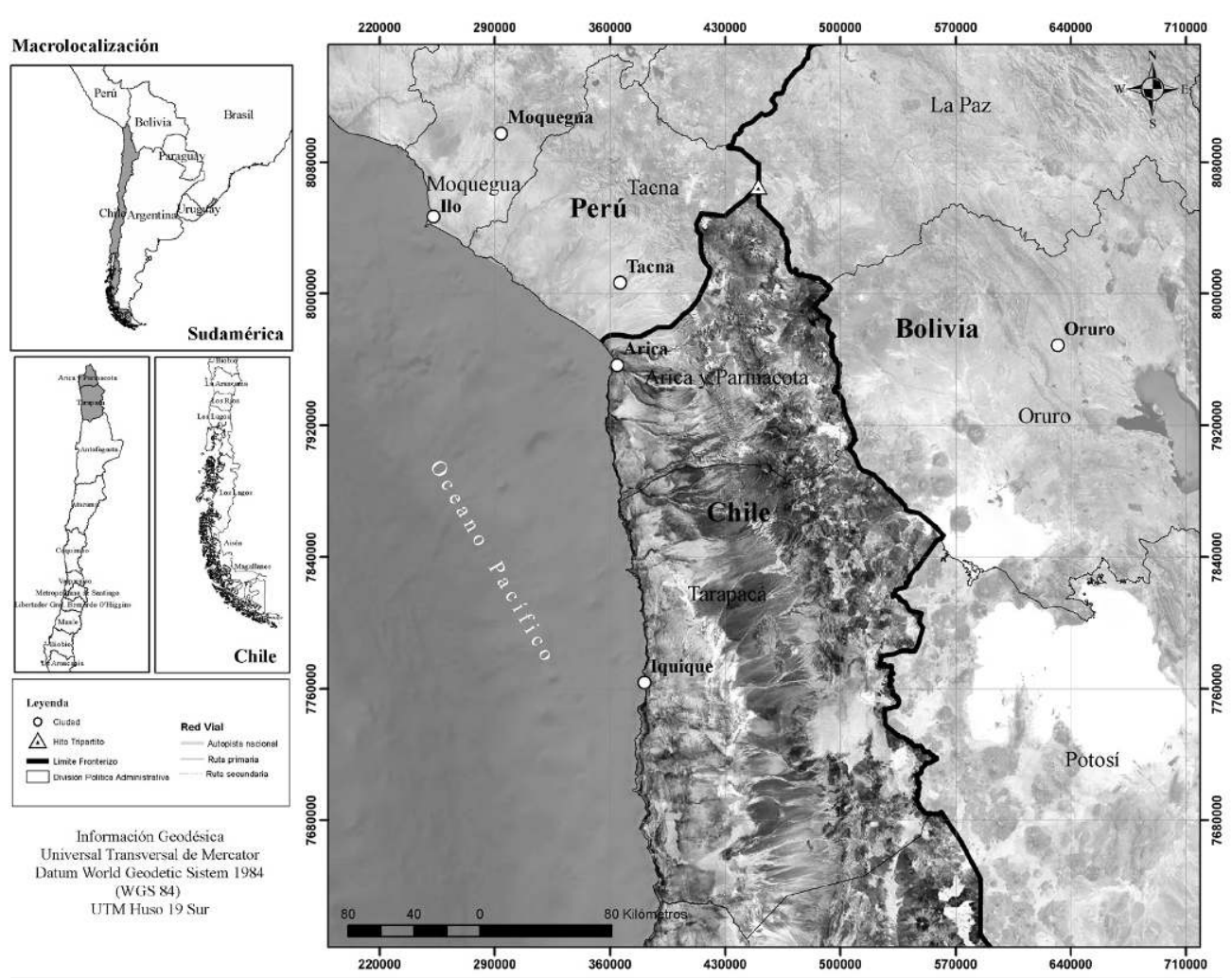

Información Geodésica Universal Transversal de Mercator Datum World Geodetic Sistem 1984 (WGS 84) UTM Huso 19 Sur

Map 1 - The Andean tri-border area (Chile, Peru, Bolivia): national limits and orography.

from my point of view, to answer this question coherently, it is necessary to displace the focus from "reality" to the "production of reality." By the latter I mean that if the remembering of this "fact" was not central to the "Chileanization" of the region of Arica and Parinacota, it would be easily "forgotten." The "Bolivianization" of these rains, which constitute an important event across the entire Andean Plateau, reaffirms the otherness of the (Chilean) Aymara people that live in these territories. For them, the rains are a central element to their experience of space, impacting significantly on their productive processes, economic organization, spatial distribution, social networks, and communitarian relationships. They also evoke their territories' ecological connection with Bolivian lands.

For the people that live in Visviri, Ancomarca and Charaña, accustomed to their villages' altitude (4000 meters above sea level), a temperature of $2^{\circ} \mathrm{C}$, with hailstorms in December presents few problems. But, for a Brazilian anthropologist, used to living in tropical climates and with a precarious resistance to the lack of oxygen, this first fieldwork experience was one funny 
scene after another. The local Aymara women, who inevitably cringed watching me on more than one occasion, responded with welcoming tenderness to my physical shortcomings whilst acclimatizing.

I had arrived in Visviri along with another anthropologist (male, Chilean and fully adapted to the highlands). ${ }^{13}$ Our plan was to stay in the village to observe the circulation of Peruvian and Bolivian workers employed in the restoration of the railroad between Arica and La Paz. ${ }^{14}$ It was also our intention to attend the Tripartite International Fair, an open market that is held on Sundays on both the Peruvian and Bolivian sides of the border. Due to the fair, the border control of people in transit is relaxed from 10:00 am to 4:00 pm: those who live in Visviri, Ancomarca and Charaña are exempted from customs and documentation controls. ${ }^{15}$ This is not the case for foreigners, who must comply with all routine inspections. At the fair, the Aymara from all three countries sell their agricultural, handicraft and manufactured products. They also interchange animals, second hand (and new) industrial products, and smuggled or counterfeit goods. Some of the exchanges do not involve money, which helps the Peruvian and Bolivian Aymara sidestep the significantly lower purchasing power of their currencies compared to Chile's. The street market was thus a singularly curious event: it established a permissiveness in border-crossings that was incoherent with the Chilean state's discourse about controlling all exchanges at these borders.

Arriving in Visviri, the first thing that caught our attention was the number of public works in the village: the square had been recently renovated, the health center was new and had impressive infrastructure. The municipal school and the municipality building had also been renovated and the streets were in the process of being paved. These renovations (and the colorful plaques with the Chilean flag and the name of the responsible ministry) announced the Chilean state's presence and the importance it placed on its local spaces at the border:

13 The colleague anthropologist, as will be explained below, played a decisive role. First, his presence made me closer to Aymara women, who preferred to talk to a foreigner woman than to a Chilean man. Due to the latter, in these initial days in Visviri, we carried out our ethnographies separately. Second, the colleague was also an important interlocutor in the analysis of the ethnographic episodes lived in the Altiplano. Despite his importance, this article is focused in highlighting my experience with the interviewees in its gender dimension: as my encounter with Aymara women that chose to exclude my male colleague of their conversations.

14 This railroad is part of the compensation offered by Chile in the treaty of 1904. It was inaugurated in 1913, and has approximately 450 kilometers, being the shortest connection between the Bolivian highlands and the Pacific coast. In 2005 an exceptionally intense rainy season destroyed part of it. The works to which I refer were intended to repair the rails for future opening. After the restoration was completed, in 2014, an earthquake of magnitude 8.2 (Richter scale) damaged the railway once again. Its reopening was then scheduled for the end of 2016.

15 Nevertheless, the Chilean Agriculture and Livestock Service (SAG, in its Spanish acronym), always applies a very strict control on the entry of plant and animal products to Chilean territory. 
both things seemed particularly out of proportion to us, given the small size of the village, which, in the Chilean census of 2002, had only 265 inhabitants (167 men and 98 women). ${ }^{16}$ The 2012 census data indicates a slight population decrease, but no important demographic changes are noticed in comparison with the 2002 census (although an increasing proportion of males and the aging process are confirmed trends in both). ${ }^{17}$ Highland villages of northern Chile have been facing the reality of an aging and declining population since the $50 \mathrm{~s},{ }^{18}$ when the Chilean state began to implement development policies emphasizing the urbanization and industrialization of its national territory, and fostering migration from the Andean Plateau to the coastal cities of Arica, Iquique and Antofagasta (Gundermann and González 2008: 86; Gundermann and Vergara 2009: 122). Since the 90s, the mining boom in Chile has been a new pull factor encouraging migration of the economically active population born in the indigenous highland villages to both the inner mining cities (such as Calama) and the coastal capitals. ${ }^{19}$

But, beyond the proliferation of public works, our attention was also drawn by the absence of people in the street: the village seemed uninhabited. We would later discover that almost everyone had gone to a neighboring village's festival celebrating the Virgin Mary. ${ }^{20}$ Despite this lack of people in the streets, the only local hostel had no available rooms: the workers hired by the Chil-

16 The public infrastructure on the Chilean side of these borders is greater than in the Peruvian and Bolivian territories. The production of such a difference is part of Chile's border strategies: it supports the discourse regarding the lack of development in Chile's neighboring countries.

17 Due to problems of sampling and analysis, the Census of 2012 was officially declared invalid and its results must be taken as an approximation. Chile has not gathered reliable and updated census data since 2002.

18 The district of General Lagos (of which Visviri is the administrative capital, and concentrates the best part of its population), had 3299 inhabitants in 1952; 1087 in 1982, 890 in 1992, 879 in 2002 and only 625 in 2012 (Vicuña et al. 2015: 41).

19 Consequently, ancestral economic activities (such as agriculture and shepherding) have suffered a disarticulation. Aymara social groups developed new economic strategies after their massive migration to the coastal cities (Gundermann and González 2008) and it fostered the organization of their political movements, which would have a significant impact on the defense of indigenous rights and interests in Chile (Gundermann 2003). The trade and smuggling activities that are also ancestrally carried out by Aymara communities have not been dismantled to the same extent that agricultural and pastoral practices have: they have suffered a functional reorganization and in fact have witnessed an increase, especially since the beginning of the present century (Garcés and Moraga 2016). The latter is related with the economic globalization of these areas, which has increased trade links with Bolivian and Peruvian localities (resulting in the rearrangement of economic complementarity between border villages) and has promoted the intensification of mobility circuits.

20 In the Andean Plateau, the celebration of the Virgin Mary promotes multidimensional interchanges between families and social groups activating historical practices of syncretism between their communitarian religious rituals (many of which predate colonization), Christian beliefs, and the nation-state's mythologies. In doing so, they endorse translocal systems of total prestations, trade routes and mobility itineraries between Chilean, Peruvian and Bolivian territories (Guerrero 2014). 
ean government (most of them Peruvians or Bolivians) for the restoration of the railway were all housed there. The lady in charge of the hotel's reception, noticing that I was freezing, told me to go to the village food store and ask if they could not put us up for at least one night. Another possibility, she said, was to ask for the city's mayor's permission to spend the night in the city hall building, or in the municipal school. But this option was unlikely for that first night, given that the mayor had also gone to the nearby festivities and would not return to the village until the following day.

The small store, where you could buy from food supplies, to cleaning and hygiene products, was served by another lady. While I was explaining our situation to her, an elderly gentleman joined our conversation, but he spoke to us in Aymara. The lady, apparently embarrassed by his interference, remarked: "Do not pay any attention to him. He is 'tata'; $; 1$ he is very old and has forgotten how to speak Spanish." The tata's lack of memory seemed an important piece of ethnographic data to me: Spanish is not usually the first language for the Aymara people of this part of the Chilean Plateau. At this stage in life, when one is inclined to selectively forget certain symbolic structures, the memory of the grandfather remained closely tied to the Aymara language. ${ }^{22}$ The lady's husband and their six-year-old daughter also appeared on the scene. Husband and wife started a lively conversation between themselves, discussing who could provide us with shelter. Afterwards, they told us about "aunt" Joanna, who lived very close by. She was in the process of renovating her home to open an informal hostel: the work was not quite finished, but perhaps the house had the necessary conditions to give us a roof over our head. Once they had it all decided the husband went off to find the aunt. While waiting, I took the opportunity to buy some food supplies for our stay, and to talk to the lady. She reiterated that, in case the aunt could not receive us, we could go over to the Bolivian side (to Charaña) where her "uncle" ran a "family and decent" residential.

When I first saw Joanna enter the store, I thought that she was about 60 years old (she told me, later in her house, that she was actually 78). She came in dressed in the typical long skirts of the area, with her hair plaited in two braids and carrying a bag of herbs, a gift for her niece. The grandfather, who was still walking in circles inside the store, greeted her and they spoke in Aymara. They all talked in this same language among themselves (most probably arranging the details of our lodging). Soon we were integrated into the conversation, and they explained to us (in Spanish) the housing conditions. The bedroom had a roof, two mattresses, and Joanna could lend us blankets

21 The word is used in Chile to refer affectionately to grandfathers.

22 His daughter's embarrassment evidences her consideration that the lack of language memory was somehow equivalent to a lack of mental health, and her conviction that it was necessary to apologize for him not remembering Spanish. 
for the night. The water and the bathroom were outside, in the yard. It was more than enough, so we went with Joanna to stay in her newly refurbished room, with its tiled floor, adobe walls and zinc roof (which provided us with a loud soundtrack when hailstones fell that first night). The room next to our bedroom was the kitchen, which had a wood-fired oven embedded in the wall. Once our luggage was in the room, Joanna looked at me with some concern. It was difficult at first for me to understand her (I was not yet familiar with the Aymara accent), but I understood her advice: I should eat before nightfall; sleeping on a full stomach would make me vomit from "apunamiento" (the local word for altitude sickness). She sent us off to the only place where we could find some food (the dining room of the railway workers). There we should talk to another "niece" of hers, who was a waitress there. The young woman, on knowing that we were staying at her "aunt's" house, was very happy to help us and gave us special treatment. We ate and retired to sleep before the storm.

\section{Women's talk}

Back at the house, my colleague went to bed, ${ }^{23}$ while I went to the kitchen to talk with Joanna, who was drinking tea and eating charqui de llama (cured llama meat). She was quick and proud to guarantee the charqui's high quality, since it was made from her own flock, and the meat had been dried and salted by a nephew, who also helped her in selling and/or exchanging it. ${ }^{24}$ She sat me next to the wood-fired oven where it was warm, and told me that she would boil water for me to wash with in the morning. On no account should I wash myself with the cold water from the yard, she insisted: I would most certainly get sick. From this moment on, our "women's talk" started. While we were eating charqui and she was knitting gloves and hats (with wool from her own llamas), she told me part of her life story. Through her narratives - full of allusions to other people's stories, and to her visits to and walks in the surrounding areas -, I began to see the way in which the national border was threaded through her and her family's itineraries.

Joanna was a widow and had sons and daughters. Her sons had migrated to work in the mining industry: some went to Iquique, others to Calama. Part of the resources for the work on her house came from these sons, who wanted to bring their own children on summer vacation and to stay comfortably in

23 Joanna did not seem comfortable talking with my colleague, which we supposed was due to him being male.

24 Absolutely everyone Joanna had referred to, and all the people with whom we had spoken so far, considered themselves either "uncles," "aunts," "nephews" or "nieces." The secondary parental relationship (with the brothers/sisters of the father or mother, uncles and aunts, or their descendants, the cousins) is not always literal. They can be socially built as a "generic affinity," forging a family's bonds and establishing complementary reciprocity to the current primary parental ties (Radcliffe-Brown 1986: 63-103). 
the village. The daughters, who lived in Arica, were married and had children. Joanna had many grandchildren, but not one of them had been born in Visviri.

She was knitting against the clock because it was time to "go down" to Arica to sell the charqui. She used these trips to trade other products as well: among them, the gloves, scarves, and hats of llama and alpaca wool that she was knitting while we talked. She put down her large knitting needles for a moment to show me, in the back room of the yard, the place where she spun, dyed and dried the wool. Adjacent to this space, there was another room where Joanna kept several colorful bedspreads of alpaca wool placed carefully on a plastic sheet that protected them from the floor. She made me feel the bedspreads pointing out that they were of very good quality; that they protected from the cold thanks to their weight (which, she commented, was a guarantee of their quality).

I never knew if she had made those bedspreads herself, or if they were exchanged. The fact is that they looked very similar to the ones made on the other side of the border (by Bolivian textile manufacturers), which were sold at various points in the Chilean highlands between Arica and Visviri. They are usually traded by the local Aymara people who advertise them as "handmade," partly to satisfy the tourist taste for "authentic" ethnic handcrafts. What I did find out for certain is that Joanna was distributing these quilts (selling them) to the tourist stores in Arica. She also traded oregano, coca tea leaves, coca leaf candy, souvenirs and anything else that could be sold at the handicraft fair, where one of her daughters (in whose house she usually stayed) ran a stand.

On her travels back from Arica, she usually takes advantage of the influx of cheap goods that arrive from the tax-free zone in Tacna (Peru), and so brings to Visviri other goods to trade: cleaning and household products, toiletries and second-hand clothes. She told me that her whole life had been spent going up and down the mountains between Visviri and Arica, just like her mother used to do. The few women who have remained in the village usually live part of the year in the highlands, and part in the coastal city. For women like Joanna, territorial mobility is central not only to their family networks, but also to their economic activities and their role in small-scale trade between the highland and coastal towns (following routes used by women since colonial times). Joanna repeatedly stressed that she liked selling; she was anxiously waiting for the moment to take her things to Arica.

Despite multi-tasking in many jobs simultaneously (like most of the village women), and although commerce occupied a fundamental part of her economy of mobility and time, Joanna identified with one of her activities in particular. For as long as she can remember, she has shepherded llamas through the mountains of the Altiplano. This work involves many hazards and requires important knowledge and skills. Due to the climatic peculiarities of the Andean plateau, the herds must cover wide areas to be able to feed properly. The shepherd must 
know the ways that lead to different types of grass and water sources. He or she must learn to differentiate the hills and furrows so as not to get lost in a terrain of predominately uninhabited lands. This activity engenders the capacity of recognizing a territory amongst landscapes that seem impossible to differentiate one from the other to the newcomer's untrained eye.

The shepherding women know these places like the back of their hands. They follow millennial grazing routes that are passed down from mother to daughter. In fact, mothers take their young children with them while shepherding. They transport them in their handmade aguayos (a rectangular and colorful fabric that is tied to the back to carry children, food and tools). Joanna's mother did that with her, with her sisters and brothers: the shepherding routes are part of the Aymara children's experiences that precede their memory. The itineraries can last many days. As Joanna told me repeatedly, it is a very hard, lonely and dangerous job that requires a lot of effort. Along these incredible mountain trails, the shepherds have built huts for shelter, usually separated from each other by a day's walk herding. To lose oneself on one of these routes can lead to the death of both the herd and the shepherdess. Failure to reach a shelter may mean having to sleep outdoors, exposing yourself as prey to wild animals (nocturnal birds or pumas, for example). To prevent these misfortunes, the shepherds usually go out armed. Joanna knows how to use a rifle, as she assured me, "very well." ${ }^{25}$ But shepherd women are not hunted only by wild animals: there have also been reports of rape carried out by men from the army, from neighboring (or their own) villages.

As if these challenges were not enough, shepherding has also become more complex for female pastoralists since the establishment of the Andean TBA in 1929. The delimitation of the frontiers in the highlands was accompanied by acts of violence from the military from the three national-states. This was even more substantial on the Chilean side, where a great effort had been made to nationalize the territory and its people, through the presence of military personnel, the deployment of landmines and controls on roads and highways (Díaz 2006). These controls created problems for those involved in grazing activities, because the boundaries have been established, in general, over ancestral routes that connected these highland locations both with cities on the Pacific coast (currently located in Chilean and Peruvian territory), and with the plateau cities (now located in Bolivian territory). Pastoralists have had to alter their grazing routes, avoiding crossing those hills that are not part of the Chilean national space and reorienting ancestral paths of herd mobility.

25 With the implementation of measures to protect the native fauna by the Chilean government, many restrictions have been established for the use of arms by shepherds. It is formally prohibited to shoot certain animals, such as the puma or the eagle. Joanna complained of these norms, alluding that those who imposed them did not understand the difficulties involved in shepherding. 
Simultaneously, the territorial and ecological conditions of the Altiplano continue to pose challenges to military technology of border demarcation: current national boundaries are spread over thousands of kilometers in the mountains (between 4000 and 6000 meters above sea level). None of the three countries has the resources to effectively control all this area.

Joanna, born around 1934, belongs to the first generation of Aymara natives who have only known the current configuration of national borders. She has experienced the state violence used in attempting to control the transit of these routes, and also the birth and development of the strategies the villagers have employed in order to continue herding and crossing the territories "as before": strategically moving through those spaces where Chilean control was not present. The shepherds of Visviri, Ancomarca and Charaña know exactly where and for how long to cross with their llamas from one side to another of the border, and have persisted doing so: "coming and going" across the three countries, their knowledge was kept hidden with secrecy. To some extent, the Aymara rely on the state's incapacity to perform effective control, and in the ignorance of the state technicians regarding where exactly the borders are placed in the mountainous areas. Logically, these practices also involve dangers. Pastors can encounter random military controls in the hills, having to answer judicially for illegally crossing the border. They can also encounter the various landmines lain by the Chilean army in these border areas. Joanna told me about her fear of them, and stories of shepherds who had been blown up after stepping on one of these artefacts.

\section{The succession problems}

With these potential dangers in mind, and worried about Joanna's physical endurance as she neared her eighties, her daughters in Arica began a family campaign to convince her to stop shepherding. Joanna resisted and had several clashes with her daughters who did not understand how important it was for her to continue with her llamas. Quitting was not acceptable for several reasons. First, because the herd was a living legacy passed down through many decades: she had cared for her grandmother's and mother's llamas. There was continuity between these women and Joanna's herd: her llamas were "of the family" in both symbolic and economic senses. To end this cycle by simply selling the herd was not only morally incorrect: it was a lack of respect. Secondly, she was especially saddened by the fact that, even though she had taught the art of shepherding to her sons and daughters, none of them wanted to take over the activity. The latter implied a personal frustration in having to face a problem caused by the economic and social changes that have led young people to migrate to the cities. These were changes that she could not control, despite having adapted to them by invoking the strategy of commercial mobility between the coastal cities and the villages of the Altiplano that her mother 
and grandmothers had already started before her. Finally, who would be left to recognize the hills if all the shepherds stopped climbing the mountains with their animals? Who would take care of the shelters and the roads? Joanna's refusal to give in to her daughters' campaign was the source of a family conflict, which led to many conversations with her relatives in Visviri.

The solution to the problem also caused conflict. With the elders' relatives from the village, Joanna concluded that this question could be settled "in the old-fashioned way." She could stop herding and deal with the lack of successors by making use of a solution that her grandparents had used in the past: pass the herd on to a nephew or niece. And so, Joanna began the search for a niece or nephew in Visviri who could relieve her of her pastoralist duties. But there was no suitable young person in the town able to do it. The aging population of the village did not help Joanna with her plans, and passing the llamas to someone of her age was not a solution. Once again, she decided to pull on the communitarian customs and to use family ties to contact a nephew of hers. He was young, and had knowledge of the mountains of Visviri (he learned about them from his father, who was an experienced shepherd). Nevertheless, this nephew (the son of a first-degree cousin of Joanna), had been born on the Peruvian side of the border.

At this point, Joanna's story became central to my reflections on transnational processes in border areas. For our protagonist, delivering her llamas to the son of her Peruvian cousin was much more coherent than extinguishing the herd. The extinction of the herd was the logic advocated by the developmental, urbanizing and de-Indianizing discourse that had been applied by the Chilean state in these areas throughout Joanna's entire life (as part of the policy of "Chileanization"). She trusted her nephew: "He is fast, he is fast. He knows the routes. He knows how to count; he is good with the llamas. He is family." They usually talk in Aymara and they understood each other perfectly, she said. She was very proud of this solution: thanks to her nephew, her animals were gaining weight: even more than they put on when she was shepherding them. In addition, Joanna's cousin and his wife, both older, were very satisfied, because they had lost part of their own herd, and so the alliance was a good way to solve their family's economic needs.

To accompany the llamas, her nephew crossed by motorcycle from Ancomarca to the Chilean side. He had to go through the controls of the Chilean Investigation Police, the Chilean Agricultural and Livestock Service, before collecting the llamas from their pen (close to Joanna's house). In the rainy months, it was not necessary to take them very far, because vegetation is more abundant. But in the driest and coldest months, her nephew herded the flock to the mountains and could spend one or two months walking them amongst the hills.

The day after this first conversation with Joanna, she offered to accompany me to the International Tripartite Fair. She wanted to introduce me to 
her Peruvian nephew, who would come to the fair to sell his family's agricultural production. She also wanted to introduce me to her Bolivian cousins from Charaña, who would bring her some handicrafts to be taken to Arica. We arrived early to the TBA milestone. As early risers, we were summoned by the Chilean, Peruvian and Bolivian military authorities to form part of the flag-raising ceremony in which the national anthems are sung. Somewhat frightened, I saw the Chilean military authority approaching us. He politely told Joanna he had chosen her to represent Chile on the spot. This scene seemed to condense, in the time it takes to sing the Chilean national anthem, almost a hundred years of "Chileanization" and masculinization of the territory. Cordially obliged to bear the Chilean flag, Joanna fulfilled her role with suspicion and seriousness.

\section{RETHINKING TRANSNATIONALISM AT THE BORDER}

Joanna's story gives us indications of several aspects of the transnational perspective that, to be applied consistently in a border area like Visviri, must be restructured. In these final remarks, I would like to focus especially on four of them. My purpose is not to reject the transnational perspective, but to point out reflections that could contribute to extending its arguments.

Firstly, Joanna's role as an agent of transnationalization of a trans-boundary space -fostering processes of migration and shared economies among Peruvians, Bolivians and Chileans - leads us to the need to re-dimension the way we have naturalized, in transnational studies, an "ideal type" (in Weberian terms) of migrant subject. Joanna allows us to understand that not every transnational subject is a migrant. Transnationalism "from below," unlike what Portes (2003) initially proposed, does not always rely on migration. In the Andean TBA, transnationalism is tied to previous translocal practices that perpetuate a remembering of the connection between territories that are now separated by borders. It is true that migrant subjects (such as Joanna's nephew) operate tensions that transnationalize the territory. But this tension is supported by the transnational agency of "locals" (in this case, Joanna). Therefore, the "transnationalism from below" depends on the articulation of two forms of transnational agency: migrant and local.

The second point refers to the definition of such "transnational social practices" as triggered by globalization. Against this background, translocal networks (especially those related to kinship systems) are the origin of the transnational structure of relations that Joanna plays, not a result of them. The Aymara families of the region constitute extensive family networks that spread their connections over considerable territories. National borders have interposed between this logic of exchange and reciprocity, separating parts of extended families, and generating differentiations of nationality that, logically, have contributed to 
dissolving certain kinship ties. But the imposition of borders and the processes that accompanied it (military, political, religious, educational and symbolic) have not been enough to break the kinship cultivated over centuries.

The solution Joanna found to her problem of succession involves at the same time the confirmation of ancestral kinship networks, the reactivation of old pastoral routes, and the maintenance of economic activity. But considering the current design of the borders, and given the dispersed positioning of the family networks in the territories of the three countries, these family activities superimpose a transnational character to the territory. Her nephew, even though he is doing something that other relatives have done for centuries, operates a transnational circulatory mobility that can be understood as a transboundary seasonal migration. In ethnographic terms, the story of Joanna's family leads us to a very important crossroads in relation to the nature of the concept of "transnational practices," demanding a diachronic perspective of such social situations. Joanna's succession solution is not exactly a social innovation, quite the opposite. Its legitimacy relies on the fact that it reproduced family networks and forms of exchange that Joanna and her kindred from the village considered "traditional" (derived from ancestral customs). Thus, the territorial mobility of the nephew is not a migratory innovation: it recovers an itinerary and an exchange system prior to the establishment of the border. We are not talking about the construction of social networks (or of a "transnational social capital," as these social networks are usually denominated) detonated by globalization. We are talking about transterritorial networks, with their own "inter-spaces" linkages, that predate the borders and that, despite the violence of the process of nationalization of the Andean Plateau, have managed to persist. The process of transnationalization of social networks precedes globalization by almost a century, because it is the national borders (established in 1929) that have given a transnational character to the translocal practices.

Likewise, the nephew can shepherd through the mountains on the Chilean side thanks to his father, who was born on the Peruvian side, and has taught him about the mountain landscapes of the Andean Plateau. The nephew and his father, and certainly also Joanna, have travelled to the mountains of the three countries adjacent to the border; and this knowledge of the territory constitutes a family cultural capital prior to the imposition of the nationstates. Therefore, we are talking about translocal mobility practices taught from father to son, from mother to daughter, that have become transnational with the imposition of borders.

But the practices developed by Joanna and her family continue to be transnational forms of territorial mobility fully connected with globalization tendencies. The recent transformations linked to the internationalization of the Chilean Plateau - the industrialization of mining, the intensification of trade 
between Bolivia, Peru and Chile, the redistribution of markets with the entry of international products into the Peruvian tax-free zone, the processes of village-city migration - shape Joanna's stories and her social experience. Her narratives are part of the globally contextualized configuration of this local space. Dialectically, they are also very particular, constituting Joanna's life experience as a singular cross-border subjectivity.

Therefore, we are facing the intensification (due to globalization) of mobility circuits which articulate at least two contradictions that defy the concepts of cultural and social capital and transnational practices in their most common definition from a transnational perspective: (1) they respond to historical patterns prior to the establishment of the nations; (2) they also respond to forms of trade prior to the political definition of what is considered licit or illicit in these territories (Cardin 2012: 232).

Third, Joanna's example reiterates that the nationalization process is as important in the current globalized connection of these cross-border areas (or perhaps even more) as its subsequent transnationalization. The transnational nature of Joanna's family members' activities can only be transnational insofar as they, as subjects, have been nationalized. The border implies the attribution of a national character and differentiation between the members of the families of the three countries. It was remarkable to me that, despite her closeness to the cousins and despite the pride she felt in recognizing her nephew as a "well-educated" young man (referring to his grazing skills and knowledge), Joanna always referred to him as "my Peruvian nephew." And the nephew, whom Joanna introduced to me, spoke of her as "my Chilean aunt." The symbolic mechanisms of identity differentiation that have characterized the nationalization of this space since the $19^{\text {th }}$ century continue to be reproduced. Identities are presented as much more malleable social forms than cultural practices (Grimson 2011). In the Andean TBA, the identities have adhered to the changes of nationalization of the territories with special and striking vehemence. But transterritorial and translocal cultural practices have not completely lost their social meaning for people. On the contrary, there is an incredible persistence of these practices among subjects of the three nationalities, even when their protagonists interpret a national difference of identities among themselves. This refers to Barth's (1976) discussion about the capacity of social groups undergoing assimilation processes to make their social practices coexist with the dominant group's (in this case, the nationstates) identity impositions.

Fourthly, and deriving from the latter, the analytical emphasis should not rely only on reconstructing the current transnational practices. Rather, we should reconstruct the history of these practices in the past, to understand and make visible the recurrences, the permanencies, and the changes they have suffered due to the emergence of the borders (in the $20^{\text {th }}$ century) and their globalization 
(in the $21^{\text {st }}$ century). This call for a radically diachronic view of current transnational practices derives from a conceptual need: to incorporate translocalism as a fundamental concept of transnational migration studies in border territories.

The anthropology of transnational practices in cross-border areas requires the ethnographer to assume a critical position about the relation between diachronic perspective and ethnographic narration (Comaroff and Comaroff 1992: 17). This would lead us to incorporate the dialectical ethnographic approach, focusing on "the reciprocal interplay of human practice, social structure, and symbolic mediation, an interplay contained within the process of articulation between a peripheral community and a set of encompassing sociocultural forces" (Comaroff 2013: 3). This implies recognizing that human beings act by determining their own history, but through contradictory mechanisms: "in their everyday production of goods and meanings, acquiesce yet protest, reproduce yet seek to transform their predicament" (Comaroff 2013: 3). No one better than Joanna, with her translocalism and transnationalism, invites us to take charge of these contradictions, instead of dissolving them in narrative.

\section{REFERENCES}

AGNEW, John, 2008, "Borders on the mind: re-framing border thinking", Ethics and Global Politics, 4: 175-191.

AMILHAT, Anne-Laure, 2007, "Are borders more easily crossed today? The paradox of contemporary trans-border mobility in the Andes", Geopolitics, 12 (1): 1-18.

BARTH, Fredrik, 1976, Los Grupos Étnicos y Sus Fronteras: La Organización Social de las Diferencias Culturales. México, DF, Fondo de Cultura Económica.

BECKMAN, Erica, 2009, "The creolization of imperial reason: Chilean state racism in the war of the Pacific", Journal of Latin American Cultural Studies, 18 (1): 73-90.

BESSERER, Federico, 2004, Topografias Transnacionales: Hacia Una Geografia de la vida Transnacional. México, DF, Editorial Plaza y Valdés.

BRENNA, Jorge, 2011, "La mitología fronteriza: Turner y la modernidad", Estudios Fronterizos, 12 (24): 9-34.

BURAWOY, Michael, 1998, "The extended case method", Sociological Theory, 16 (1): 4-33.

CARDIN, Erik, 2012, "Trabalho e práticas de contrabando na fronteira do Brasil com o Paraguai”, Revista Geopolíticas, 3 (2): 207-234.

CLIFFORD, James, 1997, "Spatial practices: fieldwork, travel, and the disciplining of anthropology", in Akil Gupta and James Ferguson (eds.), Anthropological Locations: Boundaries and Grounds of a Field Science. Berkeley, University of California Press, 185-222.

COMAROFF, Jean, 2013, Body of Power, Spirit of Resistance: The Culture and History of a South African People. Chicago, University of Chicago Press. 
COMAROFF, John, and Jean COMAROFF, 1992, Ethnography and the Historical Imagination. Boston, Westview Press.

DES CHENE, Marie, 1997, "Locating the past", in Akil Gupta and James Ferguson (eds.). Anthropological Locations: Boundaries and Grounds of a Field Science. Berkeley, University of California Press, 66-85.

DÍAZ, Alberto, 2006, "Aymaras, peruanos y chilenos en los Andes ariqueños: resistencia y conflicto frente a la chilenización del norte de Chile", Revista de Antropología Iberoamericana, 1 (2): 269-310.

DILLEHAY, Tom, and Lautaro NÚÑEZ, 1988, "Camelids, caravans, and complex societies in the south-central Andes", in N. J. Saunderns and O. Montmollin (eds.), Recent Studies in Pre-Columbian Archaeology. Oxford, BAR, 603-634.

EVENS, Terry, 2006, "Some ontological implications of situational analysis", in Terry Evens and Don Handelman (eds.), The Manchester School: Practice and Ethnographic Praxis in Anthropology. New York, Berghahn Books, 49-63.

EVENS, Terry, and Don HANDELMAN, 2006, "The ethnographic praxis of the theory of practice", in Terry Evens and Don Handelman (eds.), The Manchester School: Practice and Ethnographic Praxis in Anthropology. New York, Berghahn Books, 1-12.

FABIAN, Johannes, 2002, Time and the Other: How Anthropology Makes Its Object. New York, Columbia University Press.

FREEMAN, Carla, 2001, "Is local : global as feminine : masculine? Rethinking the gender of globalisation”, Signs, 26 (4): 1007-1037.

GARCÉS, Alejandro, and Jorge MORAGA, 2016, "Ground transportation and new interconnections between Aymara society and the new economy”, Chungara, 48 (2): 441-451.

GLICK SCHILLER, Nina, Linda BASCH, and Cristina BLANC-SZANTON, 1992, "Transnationalism: a new analytic framework for understanding migration", Annals of the New York Academy of Sciences, 645 (1): 1-24.

GLUCKMAN, Max, 2006, "Ethnographic data in British social anthropology", in Terry Evens and Don Handelman (eds.), The Manchester School: Practice and Ethnographic Praxis in Anthropology. New York, Berghahn Books, 13-22.

GONZÁLEZ, Sergio, 2006, Arica y la Triple Frontera: Integración y Conflicto entre Bolivia, Perú y Chile. Iquique, Aríbalo Ediciones.

GONZÁLEZ, Sergio, 201 1, "El Norte Grande de Chile: la definición histórica de sus límites, zonas y líneas de fronteras, y la importancia de las ciudades como geosímbolos fronterizos", Revista de Historia Social y de las Mentalidades, 2 (13): n/p.

GRIMSON, Alejandro, 2000, “iFronteras políticas versus fronteras culturales?”, in Alejandro Grimson (ed.). Fronteras, Naciones e Identidades. Buenos Aires, CICCUS, 9-40.

GRIMSON, Alejandro, 2003, "Disputas sobre las fronteras", in S. Michaelsen and D. Johnson (eds.), Teoría de la Frontera: Los Límites de la Política Cultural. Barcelona, Gedisa, 13-23.

GRIMSON, Alejandro, 2005, "Cortar puentes, cortar pollos: conflictos económicos y agencias políticas en Uruguayana (Brasil) - Libres (Argentina)”, in Roberto Cardoso de Oliveira and Sthepen Baines (eds.), Nacionalidade e Etnicidade em Fronteiras. Brasilia, UNB.

GRIMSON, Alejandro, 2011 , Los Limites de la Cultura: Crítica de las Teorías de la Identidad. Buenos Aires, Siglo XXI.

GUERRERO, Bernardo, 2014, "Religión y patria: bailes chilenos en la fiesta de Ayquina", Alpha (Osorno), 38: 89-100. 
GUIZARDI, Menara, 2016, "The boundaries of self: reappraising the social simultaneity of transnational migrant communities", in Gert Melville and Carlos Ruta (eds.), Potency of the Common: Intercultural Perspectives about Community and Individuality. Berlin and Munich, De Gruyter Oldenbourg, 377-410.

GUIZARDI, Menara, and Alejandro GARCÉS, 2012, "Mujeres peruanas en las regiones del Norte de Chile: apuntes preliminares para la investigación”, Estudios Atacameños, 44: 5-34.

GUIZARDI, Menara, and Alejandro GARCÉS, 2013, "Circuitos migrantes: itinerarios y formación de redes migratorias entre Perú, Bolivia, Chile y Argentina en el Norte Grande chileno", Papeles de Población, 19 (78): 65-110.

GUNDERMANN, Hans, 2003, "Sociedades indígenas, municipio y etnicidad: la transformación de los espacios políticos locales andinos en Chile", Estudios Atacameños, 25: 55-77.

GUNDERMANN, Hans, and Héctor GONZÁlEZ, 2008, "Pautas de integración regional, migración, movilidad y redes sociales en los pueblos indígenas de Chile”, Universum, 1: 82-115.

GUNDERMANN, Hans, and Jorge VERGARA, 2009, "Comunidad, organización y complejidad social andinas en el norte de Chile”, Estudios Atacameños, 38: 107-126.

GUPTA, Akhil, and James FERGUSON, 1997, "Discipline and practice: 'the field' as site, method, and location in anthropology", in Akhil Gupta and James Ferguson (eds.), Anthropological Locations: Boundaries and Grounds of a Field Science. Berkeley, University of California Press, 1-47.

HANNERZ, Ulf, 1986, "Theory in anthropology: small is beautiful? The problem of complex cultures”, Comparative Studies in Society and History, 2: 362-367.

KEARNEY, Michael, 1991, "Borders and boundaries of state and self at the end of Empire", Journal of Historical Sociology, 4 (1): 52-74.

KEARNEY, Michael, 1995, "The local and the global: the anthropology of globalisation and transnationalism”, Annual Review of Anthropology, 24: 547-565.

KEARNEY, Michael, 2004, “The classifying and value-filtering missions of borders", Anthropological Theory, 4 (2): 131-156.

LARSON, Broke, 1995, "Andean communities, political cultures, and markets: the changing contours of a field", in O. Harris and E. Tandeter (eds.), Ethnicity, Markets, and Migration in the Andes: At the Crossroads of History and Anthropology. Durham, Duke University Press, 5-54.

LEVITT, Peggy, and Nina GLICK SCHILLER, 2004, "Conceptualizing simultaneity: a transnational social field perspective on society”, International Migration Review, 38 (3): 1002 -1039 .

LEVITT, Peggy, and Nadya JAWORSKY, 2007, “Transnational migration studies: past developments and future trends", Annual Review of Sociology, 33: 129-156.

MANGAN, Jane, 2005, Trading Roles: Gender, Ethnicity, and the Urban Economy in Colonial Potosí. Durham, Duke University Press.

MARCUS, George, 1995, "Ethnography in/of the World System: the emergence of multisited ethnography”, Annual Review of Anthropology, 24: 95-1 17.

MASSEY, Douglas, et al., 1993, "Theories of international migration: a review and appraisal”, Population and Development, 19 (3): 431-466.

McEVOY, Carmen, 2011 , Guerreros y Civilizadores: Política, Sociedad y Cultura en Chile durante la Guerra del Pacífico. Santiago, Ediciones UDP. 
MITCHELL, Clyde, 2006, "Case and situation analysis", in T. M. S. Evens and D. Handelman (eds.), The Manchester School: Practice and Ethnographic Praxis in Anthropology. New York, Berghahn Books, 23-44.

PERKMANN, Markus, and Ngai-Ling SUM, 2002, Globalisation, Regionalization and Cross-Border Regions: Scales, Discourses and Governance. London, Palgrave Macmillan.

PORTES, Alejandro, 2000, "Social capital: its origin and applications in modern sociology", in E.L. Lesser (ed.), Knowledge and Social Capital: Foundations and Applications. Woburn, Butterworth-Heinemann, 43-57.

PORTES, Alejandro, 2003, "Theoretical convergencies and empirical evidence in the study of immigrant transnationalism”, International Migration Review, 37 (3): 874-892.

RADCLIFFE-BROWN, Alfred, 1986, Estructura y Función en la Sociedad Primitiva. Barcelona, Planeta Agostini.

ROJAS, Nicolás, and Sebastián BUENO, 2014, "Redes de inclusión: estudios sociolaborales de migrantes en Arica”, in Nicolás Rojas and José Tomás Vicuña (eds.), Migración y Trabajo: Estudio y Propuestas para la Inclusión Sociolaboral de Migrantes en Arica. Santiago, OIM, 56-100.

SATER, William, 2007, Andean Tragedy: Fighting the War of the Pacific, 1879-1884. Lincoln, University of Nebraska Press.

SEMPAT, Carlos, 1995, "Exchange in the ethnic territories between 1530 and 1567: the visitas of Huanuco and Chucuito", in O. Harris and E. Tandeter (eds.), Ethnicity, Markets, and Migration in the Andes: At the Crossroads of History and Anthropology. Durham, Duke University Press, 101-134.

STERN, Steve, 1995, "The variety and ambiguity of native Andean intervention in European colonial markets", in O. Harris and E. Tandeter (eds.), Ethnicity, Markets, and Migration in the Andes: At the Crossroads of History and Anthropology. Durham, Duke University Press, 73-100.

SUM, Ngai-Ling, 2003, "Rethinking globalisation: re-articulating the spatial scale and temporal horizons of trans-border spaces", in N. Brenner, B. Jessop, M. Jones and G. Macleod (eds.), State/Space: A Reader. Oxford, Blackwell Publishing, 208-224.

TAPIA, Marcela, 2012, "Frontera y migración en el norte de a partir del análisis de los censos población: siglos XIX- XXI”, Revista de Geografía Norte Grande, 53: 177-198.

VICUÑA, José Tomás, et al., 2015, "Características económicas y socio-demográficas de la región de Arica y Parinacota”, in José Tomás Vicuña and Tomás Rojas (eds.), Migración Internacional en Arica y Parinacota: Panoramas y Tendencias de Una Región Fronteriza. Santiago, Ediciones Universidad Alberto Hurtado, 37-48.

VITALE, Luis, 201 1, Interpretación Marxista de la Historia de Chile. Santiago, LOM.

Receção da versão original / Original version

Receção da versão revista / Revised version

Aceitação / Accepted
$2016 / 11 / 26$

$2018 / 02 / 02$

$2018 / 02 / 28$ 